\title{
El arte de la palabra y palabras de arte: narración, diálogo y descripción en Luciano
}

\section{The Art of Speaking and the Words of Art: Narration, Dialogue and Description in Lucian}

\author{
Pilar Gómez ${ }^{1}$ \\ Universitat de Barcelona (España)
}

Recibido: 15-02-19

Aprobado: 06-03-19

\section{Resumen}

La asociación entre arte y literatura puede rastrearse con facilidad en la cultura occidental desde la Antigüedad grecolatina. En un contexto literario muy marcado por la retórica, Luciano de Samosata apela a menudo, en obras de distinto registro e intención, al arte y a sus representantes como metáfora y referente de la tarea del literato, orador, sofista o escritor. El objetivo de este trabajo es revisar algunos de esos textos en los que Luciano, al amparo de símiles y metáforas artísticas, reflexiona sobre la técnica necesaria en la creación literaria, pero, ante todo, sobre la debida aplicación del arte de la palabra; y, también, observar cómo la técnica retórica que preside su producción y utiliza para describir imágenes pintadas, también guía su destreza compositiva sea en piezas narrativas o dialógicas.

Palabras-clave: Luciano, arte, retórica, écfrasis, prolaliá, diálogo.

\footnotetext{
1(pgomez@ub.edu). Doctora en Filología Clásica, profesora titular de Filología Griega en la Universitat de Barcelona, miembro del grupo de investigación Graecia Capta (UB), y colaboradora del proyecto Satira Antica (Università Ca' Foscari). Su principal ámbito de estudio es la literatura griega de época imperial romana y algunos de sus autores, en especial Luciano, en cuya edición crítica y traducción para la colección Alma Mater (C.S.I.C.) participa. Publicaciones recientes: "Voces del Hades, decretos del más allà: la consulta a los muertos en Luciano", Revista de Estudios Clásicos 43 (2016); "Dos farsantes en acción: Alejandro y Peregrino, o la retórica de la religión en Luciano" (en La satira del successo, Mimesis Edizioni, Milano/Udine, 2017); "Apuntes de un sofista cristiano en torno a la literatura griega: Ad adulescentes de Basilio el Grande", Emerita LXXXVI 2 (2018); [con F. Mestre] "The Heroikos of Philostratus: A Novel of Heroes, and more" (en Cultural Crossroads in the Ancient Novel, de Gruyter, Berlin/Boston, 2018).
} 


\begin{abstract}
The association between art and literature can be traced in the history of Western culture since Graeco-Roman Antiquity. In a literary context in which rhetoric plays a predominant role, Lucian of Samosata often appeals to art and its representatives as a metaphor and reference point for rhetors, sophists and writers. The aim of this paper is, first, to review some texts (of different register and intention) in which, using artistic similes and metaphors, Lucian reflects on the technique needed for literary creation, but, above all, on the proper application of the art of speaking; second, to observe how the rhetorical technique which presides over Lucian's production, and which he uses to describe painted images, also guides his talent in narrative or dialogical compositions.
\end{abstract}

Key-words: Lucian, art, rhetoric, ecfrasis, prolaliá, dialogue.

\title{
Introducción
}

\author{
Diérame ahora la locura \\ que en aquel tiempo me tenía, \\ para pintar la Poesía, \\ con el pincel de la Pintura.
}

Rafael Alberti, 1917 [A la pintura, poema del color y la línea, 1948]

Estos versos de Alberti son un eslabón de la larga cadena que desde la Antigüedad ha trenzado en la cultura occidental una íntima relación entre el arte y la palabra, como ya reflejaba el tópico horaciano ut pictura poesis (ars 361). Con esta expresión el poeta latino reformulaba, a su vez, una afirmación del griego Simónides, quien -recuerda Plutarco- "llama a la pintura poesía

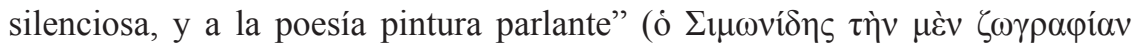

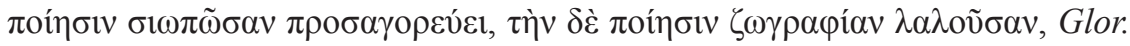
Ath. 346f) $)^{2}$. Plutarco explica que dicha afinidad se debe a que los pintores muestran como si estuvieran aconteciendo las hazañas que los poetas narran y describen como sucedidas, porque ambos representan, imitándolos, unos mismos hechos, y solo difieren en la forma y en los modos de su ejecución,

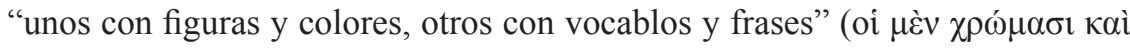

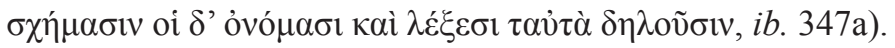

\footnotetext{
${ }^{2}$ Simon. T. 101 Poltera.
} 
El texto de Plutarco habla de $\mu$ í $\mu$ бıc. Ya Aristóteles (Po. 1448b 4-19) había asociado la imitación con las dos causas naturales subyacentes en el

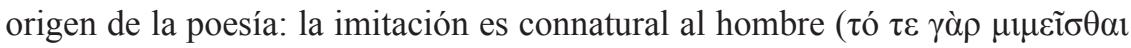

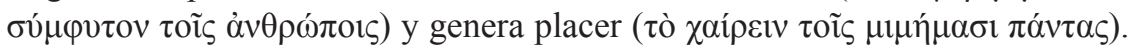
De este modo, incluso aquello que produce desagrado cuando es visto al natural, gusta cuando se contempla en imágenes, pese a la fidelidad de estas; y, por otra parte, aunque no se conozca el original, esas imágenes causan deleite estético por su color o sus formas. Por ello, el gozo derivado del efecto mimético de la poesía no es -a juicio de Aristóteles- patrimonio exclusivo de hombres eruditos, amantes del saber, sino susceptible de ser experimentados por todos los individuos ${ }^{3}$.

\section{Literatura, retórica e imitación}

El concepto de imitación inherente a la creación artística -plástica o literaria- deviene una directriz fundamental en la literatura griega de época imperial romana, identificándose en los primeros siglos de nuestra era con una

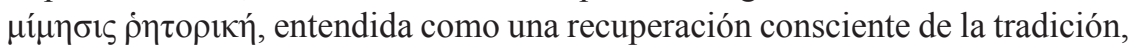
como un retorno a la sabiduría y a las obras del pasado, como un uso del legado cultural griego convertido en el fin mismo de la acción creativa del escritor; y todo esto en un estrecho nexo entre cultura literaria y técnica retórica ${ }^{4}$.

La literatura griega de este período presenta un acentuado cuño retórico, dado que en todos sus representantes fue determinante el paso por la escuela del rétor ${ }^{5}$. Esta era un espacio y un tiempo de formación cuya mecánica pedagógica, basada en ejercicios preparatorios, los llamados $\pi \rho \circ \gamma v \mu v \alpha ́ \sigma \mu \alpha \tau \alpha^{6}$, se orientaba al aprendizaje, dominio y asimilación de los autores clásicos a partir de la observación, identificación, definición, clasificación, explicación, variación y evaluación de un texto tomado como modelo y la subsiguiente producción propia de un texto similar. No obstante, una rutina escolar tan codificada como confirman los manuales de dichos ejercicios- abría, a su vez, un amplio abanico de posibilidades, cuyos resultados podrían oscilar entre dos extremos: una imitación servil y mecánica de esos modelos aprendidos y practicados; o

\footnotetext{
${ }^{3}$ Plu. Aud. poet. 17 f-18 destaca el valor de la imitación en el carácter educativo e instructivo de la poesía.

${ }^{4}$ Whitmarsh (2001: 41-89).

5 El vínculo entre retórica y literatura no se da solo en los autores griegos y paganos, sino que la obra de los autores cristianos, en los primeros siglos de nuestra era, al inscribirse en el seno de la misma tradición helénica, también queda afecta a las prácticas contemporáneas. Whitmarsh (2005: 5), Quiroga (2007: 34-35).

${ }^{6}$ Morgan (1998: 190-226), Cribiore (2001: 229-230), Webb (2001: 289-316; 2017: 139-153). El rétor Teón (Prog. 70) aboga por la utilidad de los progymnásmata en las formas oratorias, pero también en los demás géneros literarios.
} 
bien, la exploración, siempre en el marco de la tradición literaria, de nuevas formas, de nuevos géneros, teniendo en cuenta que la idea de originalidad es ajena a la literatura clásica.

Luciano de Samosata (s. II d. C.), escritor griego, nacido en la provincia romana de Comagene, en Siria, ilustra este contexto formativo y literario cuando, en diveros pasajes de su extensa y variada obra, plasma el señorío absoluto de Retórica. En Maestro de oradores lo hace mediante una imagen plástica, que él

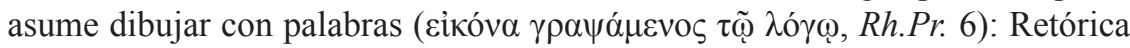
es representada como una opulenta dama que en lo alto reina rodeada de fama, riquezas, poder y elogios, sosteniendo en su propia mano el cuerno de Amaltea; y esa cima es la meta que cualquier orador $-y$, por ende, escritor y hombre de letras- debe alcanzar para lograr la felicidad suma y obtener la admiración de todos $(\theta \alpha v \mu \alpha \sigma \tau \text { ò } \varsigma \pi \tilde{\alpha} \sigma \mathrm{l} \delta \text { ó } \xi \varepsilon 1 \zeta, i b .8)^{7}$.

En un sentido paralelo, en una obra de registro autobiográfico, Luciano recuerda que su destino era seguir el oficio familiar de escultor, pero la visión durante un sueño de dos mujeres que rivalizaban por atraer su atención, acabó determinando su futuro ${ }^{8}$. El aspecto de la primera - una personificación de

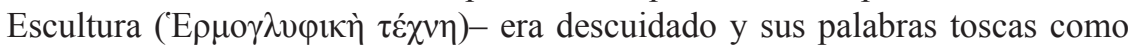
sus manos. En cambio, la noble y elegante apariencia de la segunda -se trataba de $\Pi \alpha 1 \delta \varepsilon i ́ \alpha$ en persona-, seducen al joven aprendiz cuando, con una bella dicción, le detalla qué podrá aprender y obtener a su lado, y, por el contrario, qué perderá si opta por permanecer junto a Escultura y renuncia a frecuentar la

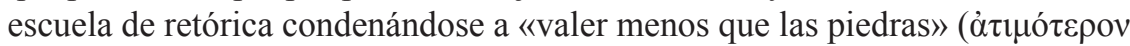

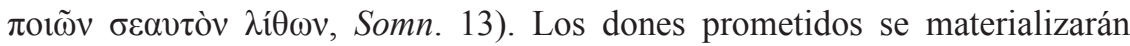
para el orador en honores, fama, elogio, distinciones, aplausos y admiración, recibidos por doquier y acompañados de poder y riqueza. Luciano explica así -en un relato que recuerda escenas de iniciación poética9 - cómo se convirtió en uno de los sofistas conferenciantes que recorrían las ciudades del Imperio, haciendo gala de habilidades oratorias y de un vasto conocimiento de la tradición literaria y cultural griega, en sesiones de exhibición declamatoria $\dot{\varepsilon} \pi \imath \delta \varepsilon^{\prime} \xi \varepsilon 1 \varsigma$ - que tenían lugar en edificios públicos (teatros, auditorios, salas de consejo...) o en recintos privados, tanto ante una numerosa concurrencia como, sobre todo, frente a un público selecto, instruido, que asistía a esos espectáculos de la palabra en los que los sofistas improvisaban sobre un tema o pronunciaban un discurso previamente preparado ${ }^{10}$.

\footnotetext{
${ }^{7}$ Gómez (2005: 329-340). Gibson (2012: 89-110) enfatiza el carácter retórico escolar de esta pieza al considerarla la refutación irónica de una máxima, una $\chi \rho \varepsilon i ́ \alpha$, atribuida a Isócrates.

${ }^{8}$ Humble y Sidwell (2006: 213-225).

9 Gómez (1994: 208-211).

${ }^{10}$ La improvisación en el discurso - habilidad y técnica inaugurada por Gorgias-a partir de temas seleccionados por el auditorio, es considerada por Filóstrato (VS 519, 600, 612, 614, 627...) como una competencia decisiva del auténtico sofista (Mestre y Gómez 1998: 352-355). Algunos sofistas (v. gr., Aristid. Or. L 69, LI 29-34 Keil, Lib. Or. 3) incluso atestiguan cómo se convocaban y se desarrollaban 
Sin embargo, Luciano es un sofista algo distinto a sus coetáneos, a quienes incluso critica abiertamente, y su nombre no aparece en la obra que Filóstrato dedicó a los representantes de la Segunda Sofística ${ }^{11}$. Se diferencia de ellos, precisamente, porque es consciente de los riesgos que una imitación a ciegas, convertida en puro servilismo y anclada solo en los moldes y en los tópicos escolares, comporta en la performance oratoria y en el proceso de creación literaria. Consecuente con ello, en sus textos arremete sarcástico contra quienes enseñan y contra quienes practican de forma inapropiada el arte de la palabra, que debe ser alimentado por una saludable emulación de arquetipos adecuados, pero sin provocar hartazgo, como le ocurrió a un tal Lexífanes. Este 'exhibidor de palabras'-según indicaría su nombre- es víctima de una indigestión léxica debida a su pasión desmedida por la lengua ática, a su exagerado aticismo ${ }^{12}$, pues "habla como mil años antes, distorsiona el lenguaje, y compone estas palabras insólitas, tomándolas muy en serio, como si fuera algo realmente grande el hecho de emplear un vocabulario extraño y falsificar la moneda corriente del habla" (Lex. 20); y también por los excesos de una mal aprendida y peor aplicada mímesis, a juzgar por los pasajes que Lexífanes lee de su Banquete $^{13}$, donde el género simposial ha quedado reducido a la gestualidad de los comensales y a los elementos materiales del festín, como delatan el minucioso inventario de un ridículo menú o el intercambio de altisonantes parlamentos vacíos de contenido ${ }^{14}$. La ironía de Luciano no significa falta de confianza en el modelo formativo, ya que para él Paideía es la fuente de todas las virtudes. Así pues, el único remedio para la enfermedad de Lexífanes, si quiere llegar a ser alguien en las letras, y no una muñeca de barro, coloreada por fuera, pero muy frágil por dentro ${ }^{15}$, es que vuelva a aprender -como denotan los términos $\mu \varepsilon \tau \alpha \mu \alpha v \theta \alpha ́ v \omega v(L e x .23)$ у $\mu \varepsilon \tau \alpha \mu \alpha ́ \theta n \varsigma$ (Lex. 25)- con la precaución de seguir solo el consejo de quienes saben hacer uso de una genuina instrucción

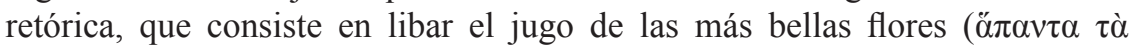

esas exhibiciones oratorias, quiénes asistían, etc. Sobre la relación entre sofista y público en Luciano, Favreau Linder (2009: 422) afirma: "Spectateur et témoin des performances sophistiques, Lucien met en lumière les attentes du déclamateur et du public lors de ces conférences".

${ }_{11}$ Philostr. VS 480-481 para la denominación de este movimiento. El creciente interés por la Segunda Sofística entre los estudiosos del mundo clásico se refleja en las nuevas perspectivas de análisis que sobre su interpretación y significado ofrece el reciente handbook editado por Richter y Johnson (2017).

${ }^{12} \operatorname{Kim}(2017: 49)$ actualiza la larga y debatida controversia sobre este concepto distinguiendo entre aticismo positivo y aticismo negativo, es decir, "between the use of catchwords and phrases perceived as quintessentially Attic, on the one hand, and the much more difficult avoidance of un-Attic features, on the other".

${ }^{13}$ Un "pastiche du Banquet de Platon", según Bompaire (1958: 611). Luciano censura en todo momento el perverso modo de la imitación ejecutada por Lexífanes, sin parodiar a Platón, a quien incluye siempre en su canon de autores; cf. Ind. 27, Rh.Pr. 9 y 17, Lex. 22.

${ }^{14}$ Gómez (2007: 485-496).

${ }^{15}$ Luc. Lex. 22. La comparación entre creación retórica y literaria con la alfarería es el punto de partida de A quien dijo: "eres un Prometeo en tus discursos", y aparece reiterada en Zeux. 2.

Araucaria. Revista Iberoamericana de Filosofia, Política, Humanidades y Relaciones Internacionales, año $21, \mathrm{n}^{\circ} 41$. Primer semestre de 2019. Pp. 233-256. ISSN 1575-6823 e-ISSN 2340-2199 doi: 10.12795/araucaria.2019.i41.11 


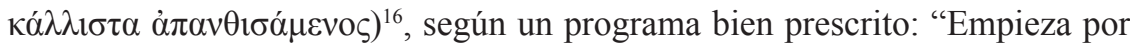
los mejores poetas y léelos bajo la directriz de maestros; pásate a los oradores $\mathrm{y}$, cuando te hayas familiarizado con su dicción, es el momento de acercarte a la

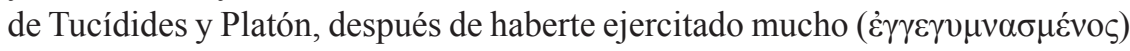
no solo en la bella comedia sino también en la venerable tragedia" (Lex. 22).

Si algo caracteriza a Luciano es quizá su carácter inclasificable ${ }^{17}$. Como adalid de una cultura auténticamente individual, aparece siempre al margen de cualquier tipo de compromiso. El conocimiento de la cultura griega que compone su universo y el dominio técnico en el arte de la palabra son por él asimilados y transformados, gracias a su genio creador imaginativo y crítico, en una paideía propia, cuyo cultivo le evita caer en la esclavitud y las malas prácticas habituales entre sus coetáneos -sean estos sofistas, filósofos, historiadores...-, que tan a menudo denuncia y todavía más teme por considerarlas peor que la ignorancia ${ }^{18}$. Solo una verdadera educación lleva a la libertad y confiere legítima sabiduría, que, ciertamente, no consiste en mantener a ultranza los cánones heredados.

Tal vez por esta razón Luciano visualiza su maestría mostrándose como un innovador en la forma de sus obras, máxime al haber dotado de nueva vida al diálogo - un género consagrado en la tradición literaria por Platón- aproximándolo a la comedia para liberarlo del peso de sus densas elucubraciones ${ }^{19}$. Esa contaminación-esa $\mu \tilde{i} \xi 1 \varsigma^{20}$ - obligó a Luciano a defenderse ante la acusación de una vulgarizada Retórica por haberla repudiado en favor del respetable Diálogo, capacitado para la reflexión y el análisis, preocupado por lo verdadero y lo auténtico, pero demasiado aburrido; por ello, el samosatense se siente orgulloso de haberle ofrecido nuevas posibilidades con ese acercamiento a la comedia, al sacarlo de su encierro y mostrarlo más atractivo para una amplia mayoría de espectadores. No obstante, Luciano es víctima de la ingratitud del propio Diálogo, ya que también este le reprocha la vejación de verse

${ }^{16}$ El término $\dot{\alpha} \pi \alpha v \theta \imath \sigma \alpha ́ \mu \varepsilon v o \varsigma$ es aplicado por Luciano también al aprendizaje filosófico (Pisc. 6), que no consiste en la utilización mecánica de preceptos filosóficos para alcanzar un legítimo conocimiento en el arte de vivir.

${ }^{17}$ Brandâo (2001: 88) define la poética (de $\pi$ oínбıৎ) lucianea como una opción compleja basada en "uma certa mímesis da diferença". Andrade y Rush (2016:151) llaman a Luciano "a cryptic figure in the history of later Greek literature".

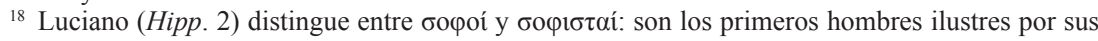
teorías, pero que también dejan pruebas de su arte, mientras que los segundos solo se ejercitan en sus palabras. Sobre la primacía del arte o de la naturaleza, Elio Aristides postula que un verdadero artista es solo el individuo capaz de superar a sus predecesores, como atestiguan Zeuxis, Parrasio, Fidias, Hipócrates o Demóstenes, quienes "destacaban por su talento y dieron honra a las artes, al no quedarse donde las encontraron" (Aristid. Or. II 120 Behr).

${ }^{19}$ Luc. Prom.Es. 6. Mestre y Gómez (2001: 114-120), Billault (2017: 37-48).

${ }^{20}$ Desde el brillante análisis de Camerotto (1998: 75-133) sobre la mezcla de variados elementos y distintos registros como principio creador en Luciano, este término ha tenido y sigue teniendo todavía una notable acogida entre los estudiosos del samosatense, como prueba, desde distintos enfoques, el volumen colectivo de Marquis y Billault (2017). 
obligado por un bárbaro sirio a renunciar a su genuina condición filosófica para dedicarse a toda ley de bufonerías, incapaz de reconocerse en su nueva -y para él extraña- categoría, una vez perdida la máscara de tragedia y de prudencia que le conferían dignidad ${ }^{21}$.

A pesar de tales acusaciones, Luciano no renuncia a definirse literariamente, a posicionarse respecto de su actividad oratoria, a reconocer el carácter innovador de su creación literaria, pero se resiste a ser identificado con un nuevo Prometeo, pese a la novedosa y extraña mezcla de sus obras

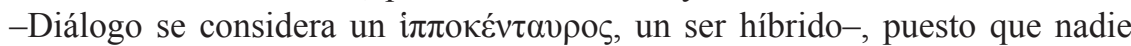
podrá acusarle de robo ni de mera invención -como le ocurrió al Titán con el fuego y por crear a los hombres cuando no existían ${ }^{22}$-, ni él tampoco -como el pintor Zeuxis- valora la novedad por ella misma ${ }^{23}$. Luciano admite que, tal vez, sus obras sean frágiles, como de arcilla, pero defiende que su oficio responde a un arte aprendido - a una $\tau \dot{\varepsilon} \chi \vee \eta —$ - que se inserta en una tradición, y en cualquier creación suya pueden ser identificados los componentes legitimados en el seno de esa tradición ${ }^{24}$.

\section{Luciano y el arte}

La personal elección de Luciano, vital y profesional, en favor de Paideía frente a Escultura es significativa porque, desde su dimensión programática, muestra también cómo, en época imperial, el arte es, a la vez, señal propia de identidad griega y, por lo tanto, forma parte de esa cultura (paideía), entendida no solo en el sentido activo de educación, sino en su valor perfectivo de plena educación ${ }^{25}$. Al igual que el legado literario, también el artístico, a través de sus representantes, de sus obras, actúa como referente común entre el escritor o el orador y el público lector u oyente -unos y otros constituyendo, por igual, el universo de los pepaideuménoi, cuya condición puede reconocerse tanto en la capacidad para rememorar una cita, un verso, las palabras -e incluso la gestualidad $^{26}$ - de un personaje, como en la aptitud para identificar el tema de una obra plástica. Las obras de arte interesan en la literatura de época imperial porque sirven de soporte a la historia, al mito, que siguen siendo sus nutrientes esenciales; y desempeñan un papel destacado en piezas de carácter netamente retórico. Por su propia esencia, la retórica explota el poder mnemónico de la imagen, de la metáfora, y las artes de la memoria son una articulación compleja

\footnotetext{
${ }^{21}$ Luc. Bis Acc. 33-34.

22 Ante la acusación de Hermes por su creación, Prometeo esgrime en su defensa que modeló a

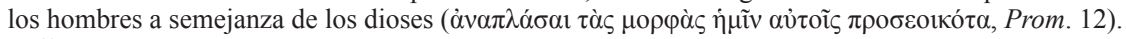

${ }^{23}$ Luc. Zeux. 7.

${ }^{24}$ Lucianus, Prom.Es. 5.

${ }^{25}$ Elsner (2013: 136-152).

${ }^{26}$ Mestre (2017: 242-255).
}

Araucaria. Revista Iberoamericana de Filosofia, Política, Humanidades y Relaciones Internacionales, año $21, \mathrm{n}^{\circ} 41$ Primer semestre de 2019. Pp. 233-256. ISSN 1575-6823 e-ISSN 2340-2199 doi: 10.12795/araucaria.2019.i41.11 
de lugares y percepciones, fundamentada en la superioridad de la vista sobre otros sentidos ${ }^{27}$; pero, al mismo tiempo, a través de los detalles de la visión y de la elaboración alegórica, advierte sobre el necesario talento plástico que escritores y oradores han de poseer para situarse en la cúspide de su arte, porque este consiste, precisamente, en moldear palabras.

Un moldeo idóneo de palabras y de temas debe dirigir el buen trabajo del hombre de letras -escritor, orador-, y Luciano es categórico al respecto,

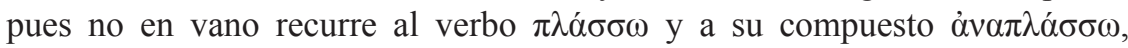
para expresar en qué consiste la tarea de un escritor ( $\gamma \rho \alpha \varphi \varepsilon v ́ \varsigma)$, de un prosista

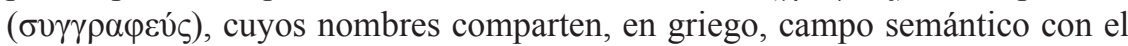
pintor $^{28}$, pero también para evidenciar sus malos hábitos. Un historiador, por ejemplo, no debe buscar qué decir, sino cómo decirlo; y en la explicación de ese procedimiento Luciano se sirve de una comparación explícita con el trabajo de los escultores invocando a Fidias, Alcamenes y Praxíteles, quienes no creaban sus materiales, sino que se limitaban a transformarlos:

\begin{abstract}
"Pues no escriben los historiadores como se hace entre los oradores, sino que lo que ha de ser expuesto existe y será dicho porque ya ha sucedido. Es menester ordenarlo y decirlo. O sea que no deben buscar qué decir, sino cómo decirlo. En definitiva, pues, hay que considerar que el escritor de historia utiliza a Fidias o se parece a Praxíteles o a Alcamenes o a algún otro de esos -en cuanto a que ellos no fabricaban oro o plata o marfil $u$ otros materiales, que ya existían y habían sido utilizados previamente cuando se los sumistraban eleos, atenienses o argivos, sino que solo los trabajaban: serraban y pulían el marfil, lo encolaban, lo iban acoplando y revistiendo con oro. Ese era su arte: tratar los materiales como es debido". ${ }^{29}$
\end{abstract}

Es, por lo tanto, una cuestión de aplicar de forma correcta una determinada $\tau \varepsilon ́ \chi v \eta$, tal como el buen historiador puede aprender con la instrucción debida para ser considerado un Fidias de la historia:

\title{
Luc. Hist.Conscr. 51
}

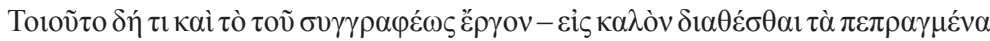

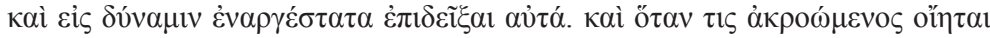

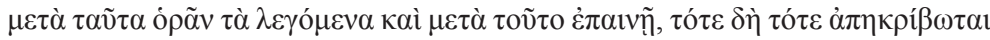

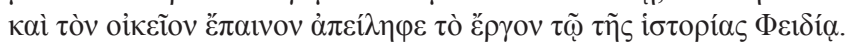

Parecida es la obra del escritor -recorrer con belleza lo sucedido y presentarlo como si estuviera vivo, con fuerza. Y, cuando alguien, en una audición posterior,

\footnotetext{
${ }^{27}$ Como formulara Cicerón: "acerrimum autem ex omnibus nostris sensibus esse sensum uidendi" (de orat. II 87,357 )

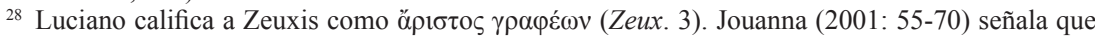

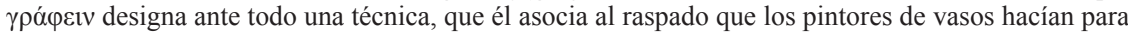
grabar en ellos su nombre.

${ }^{29}$ Luc. Hist.Conscr. 50.
} 
crea estar viendo lo expresado y seguidamente haga un elogio, entonces y solo entonces estará perfectamente acabada y la obra de este Fidias de la historia habrá alcanzado el elogio debido.

Luciano apela así a uno de los grandes nombres de la escultura griega como paradigma de buen escritor ${ }^{30}$. Ello explica que escultores anteriores a la plenitud del período clásico, cuyo estilo resulta áspero, sean mencionados por el instructor de la nueva retórica para denostar el método de aprender oratoria propulsado por viejos maestros como Demóstenes y Platón:

"Luego te ordenará que emules a aquellos antiguos hombres, proponiéndote marchitos ejemplos de discursos no fáciles de ser imitados, como las obras del antiguo taller, de Hegesias y de los seguidores de Critio y Nesiotes, densas, vigorosas, rígidas y de contornos delimitados con precisión" 31 .

En cambio, la falta de instrucción genera siempre invenciones gratuitas o exageraciones incompatibles con la verdad cuando se trata de hechos reales, acaecidos $^{32}$, porque entonces sus escritos resultan tan vacuos como las palabras de los filósofos o de un mal orador que solo dice lo primero que se le antoja:

\section{Luc. Hist.Conscr. 32}

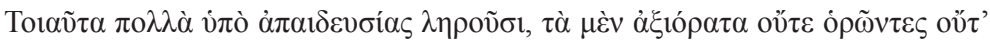

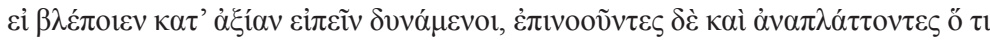

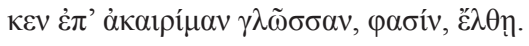

Muchas de estas tonterías las dicen por falta de instrucción: por un lado, lo que es digno de verse ni lo ven ni, si llegan a mirarlo, son capaces de hablar de ello según su importancia y, por otro, imaginan e inventan "lo primero que viene a su torpe lengua" 33 .

Sin embargo, no basta con esculpir bien las palabras, los textos, los argumentos, o con pintar una imagen con vocablos, sino que deviene necesario igualmente poner en valor la acción del lector y del público que asiste a una declamación sofística, quienes también deben 'ver' en los escritos y en los discursos.

\footnotetext{
${ }^{30}$ Sobre la reputación de Fidias, la conexión de su arte con la retórica y el uso de su nombre entre los oradores, Pernot (2011: 11-43).

31 Luc. Rh.Pr. 9. Quintiliano califica las obras de Hegesias como "duriora et tuscanicis proxima" (inst. 12.10.7).

${ }^{32}$ Distinto es, en cambio, cuando el autor inventa el contenido de una narración. En este sentido, Luciano en el prólogo de Relatos verídicos renonoce no haber tenido ninguna experiencia digna de

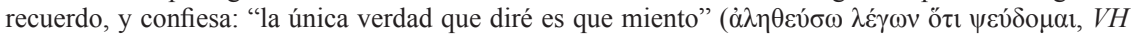
1.4). Gassino (2010: 87-98), Ní Mheallaigh (2014: 206-208).

${ }^{33}$ En Rh.Pr. 18 el rétor defensor de la nueva oratoria también cita este verso lírico anónimo ( $P M G$ Adesp. 1020), con el que Ateneo ilustra los anacronismos cometidos por Platón (Ath. 217c).
} 
El corpus lucianeo prueba esa conexión con abundantes referencias y variadas alusiones a la tradición artística, aunque todas ellas, bien se trate de artistas o de obras concretas, son siempre anteriores a época helenística ${ }^{34}$. Esa reiterada presencia de las artes plásticas en la obra del samosatense responde a finalidades bien distintas ${ }^{35}$, pero recurre de un modo significativo cuando Luciano explica cuáles son los principios que rigen su creación literaria o su actividad oratoria, convirtiéndose así él mismo en el tema de su obra, como reflejan algunas breves piezas de su repertorio, pensadas para ser ejecutadas como preámbulo de la sesión declamatoria. En efecto, antes de una conferencia, el orador solía presentarse con una composición preliminar reducida, llamada $\pi \rho \lambda_{\alpha} \alpha \lambda \alpha^{\alpha}$, que, dentro del género epidíctico, identifica un tipo de discurso, muy libre en forma y en contenido ${ }^{36}$, puesto al servicio del sofista para captar y atraer la atención del auditorio anticipando una pequeña muestra inicial de su habilidad oratoria. Esos proemios declamatorios constituyen un espacio y un momento de autocelebración, en el que Luciano, debido a su propio planteamiento como autor y orador, brilla de modo especial y tiñe incluso de una cierta autoironía ${ }^{37}$.

Algunos de los prólogos oratorios identificados en el corpus lucianeo ${ }^{38}$ reflejan abiertamente la vinculación entre palabra y arte, en particular los que toman como referencia obras específicas, porque escenifican el talento del sofista y son, mediante un juego de estrategias retóricas, una demostración de su cultura y elocuencia. De este modo, en el espacio de la $\pi \rho 0 \lambda \alpha \lambda \lambda_{1}$, el talento del sofista complementa y es complementado por el ojo experto de cualquier individuo instruido, del pepaideuménos que por su conocimiento se opone al

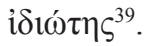

Luciano tiene a su disposición un recurso retórico idóneo para ese fin

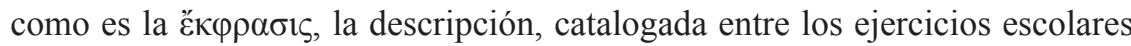
preparatorios practicados en la escuela del rétor. Por sus características, este ejercicio supone un gran desafío para el virtuosismo de un sofista, ya que dar

${ }^{34}$ Dubel (2014: 215-216) ofrece un catálogo de obras y artistas mencionados por Luciano.

35 Maffei (1994: XVIII-XX) elenca pasajes de Luciano en que obras de arte griego -"senza mai diventarne tema principale, si segnalano tuttavia come ingredienti compositivi essenziali"- son utilizadas para destacar un rasgo grotesco, explicar un concepto abstracto, identificar un lugar, aportar trazos de realidad a la pura ficción, dar a conocer curiosidades exóticas, etc. Así, por ejemplo, Luciano compara "con aquellos colosos de grandes dimensiones realizados por Fidias, Mirón o Praxíteles" (Gallus 24) la suma ignorancia de quienes consideran a Micilo un dios.

${ }^{36}$ Men. Rh. 388.17-394.31.

${ }^{37}$ Pernot (1993: 546-568), Dubel (2014: 9-16), Billault (2006: 47-59).

38 Bompaire (1958: 286-288) reseña diez: Herodoto o Etión, El escita o el cónsul, Harmónides, Acerca del ámbar o de los cisnes, Zeuxis o Antioco, Sobre las dipsadas, Proemio: Dioniso, Proemio: Heracles, El sueño o la vida de Luciano y Sobre la sala. Nesselrath (1990: 115) y Pernot (1993: 550) ponen en duda el caso de A quien dijo: "eres un Prometeo en tus palabras", mientras que Billault (2006: 48) propone excluir El sueño o la vida de Luciano por ser «a independent discourse in praise of paideia», y Sobre la sala por su mayor extensión.

39 Camerotto (1998: 266-286).

Araucaria. Revista Iberoamericana de Filosofía, Política, Humanidades y Relaciones Internacionales, año $21, \mathrm{n}^{\circ} 41$. Primer semestre de 2019. Pp. 233-256. ISSN 1575-6823 e-ISSN 2340-2199 doi: 10.12795/araucaria.2019.i41.11 
visibilidad a un objeto mediante el lenguaje o describir una pieza artística constituye la expresión más elaborada de la rivalidad entre palabra e imagen, dado que, con la complicidad del léxico de la visión, establece un campo metafórico de referencia para trazar el poder evocador del discurso ${ }^{40}$. La teoría

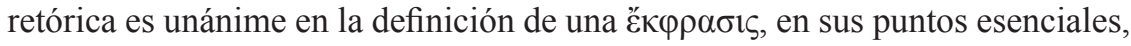
como un discurso descriptivo ( $\lambda$ ó $\left.{ }_{0} \varsigma \varepsilon \varepsilon \rho \eta \gamma \eta \mu \alpha \tau \iota \kappa o ́ \varsigma\right)$ cuya finalidad es poner

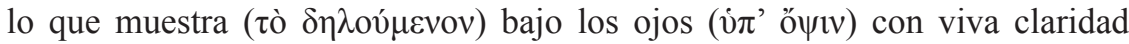
$(\sigma \alpha \varphi \eta ́ v \varepsilon 1 \alpha)$ y viveza (غ่vó $\rho \gamma \varepsilon 1 \alpha)^{41}$. Se trata de una práctica narrativa que utiliza el lenguaje para crear una especie de ventana a través de la cual el oyente o el lector visibiliza lo que es descrito, porque la descripción lleva a 'otra' realidad, visual y verbal al mismo tiempo, que es revelada por la palabra sabia y persuasiva del orador, como una suerte de juego ilusorio hecho con palabras, dado que para un oyente o un lector ese objeto, ese hecho, existe solo en la medida en que es dicho o es escrito.

En realidad, la metamorfosis de escuchar en ver fue, desde siempre, adjudicada al don que las Musas confieren a los poetas, quienes mediante la acción que expresan verbos como $\theta \dot{\varepsilon} \lambda \gamma \omega$ - ““"'enchanter, transformer ou paralyser par un charme", d'où "tromper"', según define Chantraine-, también persiguen que sus oyentes puedan ver a través del oído ${ }^{42}$. La transposición a la prosa de esa función poética la llevó a cabo Gorgias, como se constata cuando el sofista

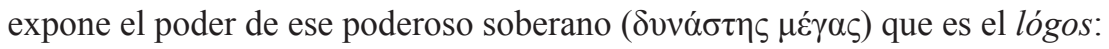

Gorg. Hel. 10

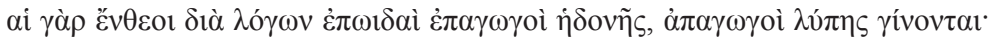

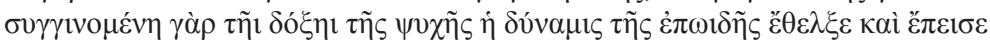

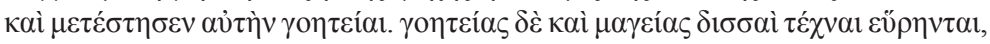

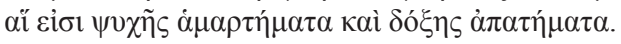

Los encantamientos inspirados por las palabras, aportan placer y apartan el dolor; pues, cuando el poder del encantamiento tropieza con el sentir del alma, la seduce, la persuade y la transforma mediante un hechizo. Del hechizo y de la magia se han inventado dos artes que son extravíos del alma y engaños de su sentir.

En efecto, si la virtud del lógos se canaliza a través de la persuasión $(\pi \varepsilon \imath \theta \omega)$ que produce en el oyente una ilusión o un engaño ( $\dot{\alpha} \pi \alpha ́ \tau \eta)$, esta es una

${ }^{40}$ Cassin (1997: 15-29). La literatura sobre la écfrasis en el mundo clásico es abundante; una rica compilación puede consultarse en Squire (2015: 16-33).

41 Theon Prog. 118-120, Hermog. Prog. 22-23, Aphth. Prog. 36-38, Nicol. Prog. 67-71. Squire (2015: 3-5) analiza la similar definición de écfrasis en estos manuales de ejercicios, cuya cronología se extiende entre los siglos I-V d. C.

42 Uno de los anónimos Discursos dobles, de origen sofístico, enuncia: “en la composición de tragedias y en la pintura, quien logra el engaño perfecto creando ficciones semejantes a la verdad, es un artista insuperable" (Dialex. 3.10).

Araucaria. Revista Iberoamericana de Filosofia, Política, Humanidades y Relaciones Internacionales, año $21, \mathrm{n}^{\circ} 41$ Primer semestre de 2019. Pp. 233-256. ISSN 1575-6823 e-ISSN 2340-2199 doi: 10.12795/araucaria.2019.i41.11 
herencia que reivindica la Segunda Sofística, desde cuya óptica logocéntrica no hay ninguna experiencia estética que pueda prescindir de la palabra, y la

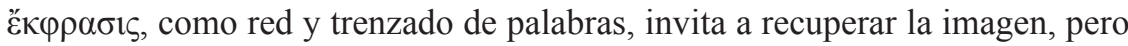
jamás la acción discursiva abdica de su hegemonía, pues de lo contrario sería solo una cuestión de $\theta \alpha \tilde{\nu} \mu \alpha$, de un hipnótico asombro ante la belleza.

\section{Ut pictor rhetor}

Así lo sugiere Luciano cuando dedica uno de sus prólogos oratorios, cuyo leitmotiv consiste en un juego entre visión y habla, a contraponer el invencible placer de contemplar algo bello a la fuerza de la palabra ${ }^{43}$. En Sobre la sala, Luciano invita a meditar sobre si es conveniente pronunciar discursos en una bella sala de declamación, a través de un supuesto àyóv entre dos oradores. El primero de ellos, aunque admite sentirse abrumado por la belleza del entorno, reconoce que aprecia como un estímulo para su actividad poder hablar en un recinto de magnífica arquitectura y majestuosa ornamentación, porque, por su

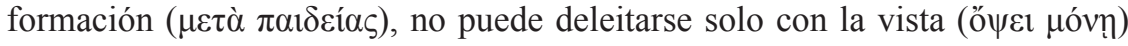
ni contentarse con ser mudo espectador (ä $\varphi \omega v o \zeta \theta \varepsilon \alpha \tau \eta ́ \varsigma$ ), sino que debe

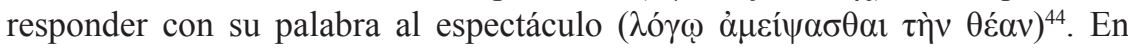
cambio, el segundo orador considera que un espacio declamatorio demasiado hermoso como la sala en que se encuentra, es un rival siempre difícil para un conferenciante porque lo sobrecoge, lo aturde, lo intimida y le infunde el temor de que, distraído en elogiar cuanto ve, su disertación sea eclipsada por el esplendor del lugar:

\section{Luc. Dom. 17}

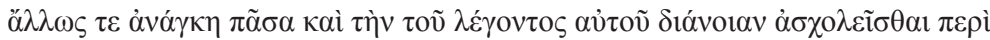

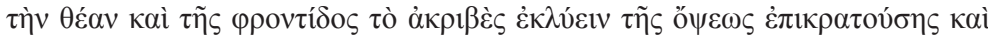

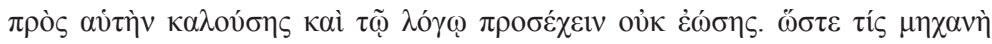

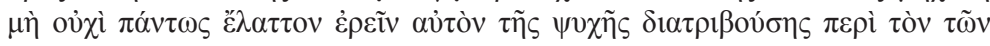

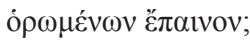

Además es de toda necesidad que el ánimo del orador esté ocupado en la contemplación y que la exactitud de su pensamiento se relaje ya que obtiene la preeminencia la visión, que le atrae y no le permite atender a su discurso. De manera que ¿cómo va a ser posible que él no hable mucho peor si su espíritu está ocupado en el elogio de los objetos que ve?

${ }^{43}$ Dobrov (2002: 173-191), Newby (2002: 126-135), Goeken (2009: 189-221).

${ }^{44}$ Luc. Dom. 2. 
Asimismo, la magnificencia y el encanto de la sala interfieren en el papel que corresponde a los asistentes puesto que, al quedar boquiabiertos por la hermosura del espacio, como le ocurre al orador, también están solo pendientes de lo que ven; y, nada más entrar, dejan de ser oyentes y acaban convertidos en meros espectadores ${ }^{45}$ :

\title{
Luc. Dom. 18
}

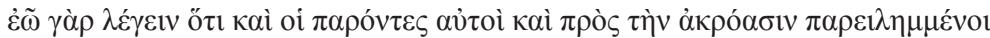

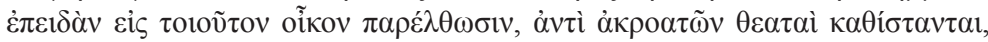

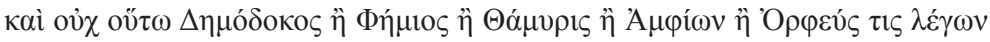

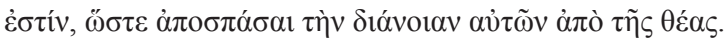

Dejo de decir que quienes están presentes y han sido invitados a la audición, cuando entran en una sala de tales características, se convierten en espectadores en lugar de oyentes, y no existe orador equiparable a Demódoco, a Femio, a Tamiris, a Amfión o a Orfeo como para hacerles apartar el ánimo de la contemplación.

Por este motivo, ese segundo orador propone que los jueces que han de resolver quién de los dos mejor ha presentado sus argumentos sobre el duelo entre palabras y objetos $-\mathrm{y}$, por extensión, también el público siempre que alguien declame en un bello espacio-, deberían seguir la audición con los ojos cerrados para valorar de forma adecuada el mérito de los oradores:

\section{Luc. Dom. 32}

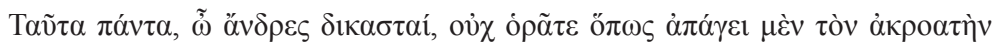

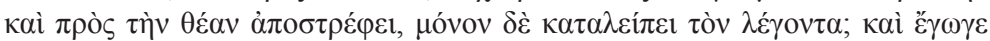

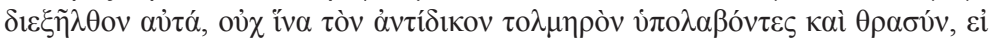

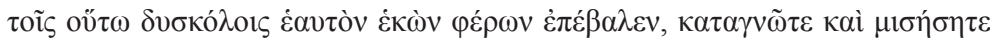

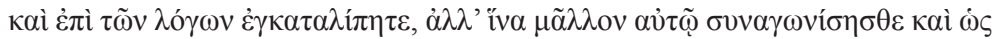

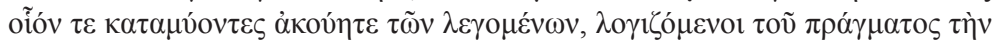
$\delta v \sigma \chi \varepsilon ́ \rho \varepsilon 1 \alpha v^{*}$

\begin{abstract}
¿No veis, jueces, cómo todas estas cosas seducen al oyente, le hacen volver hacia la contemplación y dejan solo al orador? Y yo he hecho su descripción no para que vosotros consideréis a mi rival audaz y temerario por haberse embarcado en estos peligros lanzándose voluntariamente, y le condenéis, le odiéis y le abandonéis a sus discursos, sino más bien para que le prestéis vuestra ayuda en el certamen y escuchéis sus palabras con los ojos tan cerrados como sea posible, mientras reflexionáis sobre la dificultad de la empresa.
\end{abstract}

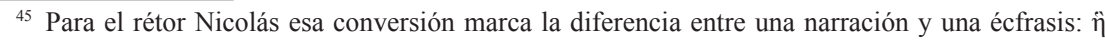

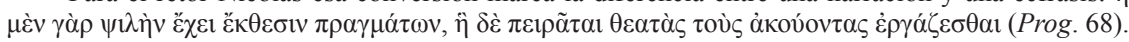


Ello significa que el público de una audición debe confiar solo en su oído para aquilatar en su justa medida la tarea del orador, como ya antes también ha manifestado de forma explícita el segundo orador cuando aclara en qué consiste, precisamente, el reto que está dispuesto a asumir al encontrarse en un espléndido auditorio: describir con sus palabras la decoración que ha cautivado la vista del público. Solo a partir de esa contraposición entre el ornato de la sala y su traslación a las palabras del orador, la concurrència -a condición de que sea necesariamente ilustrada ${ }^{46}$, , aunque esté ya fascinada por el espectáculo material del recinto-, puede poner en valor la pericia de aquel en el arte de la elocuencia, cuya finalidad es ofrecer entonces como contrapunto al espectáculo visual un espectáculo verbal, igualmente seductor:

Luc. Dom. 21

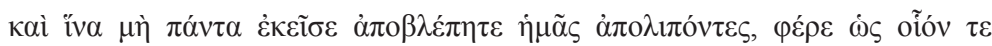

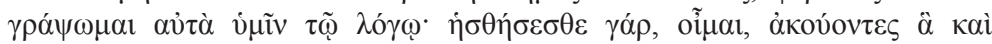

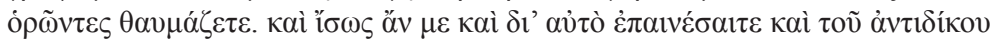

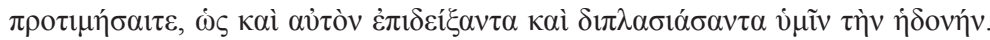

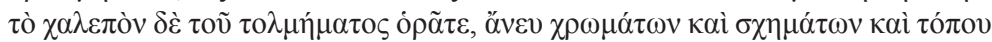

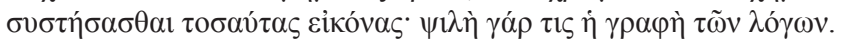

Y para que no levantéis todas vuestras miradas hacia allí, dejándonos a nosotros de lado, ¡ea!, os voy a hacer la mejor descripción que pueda con mi discurso. Disfrutareis, creo, de escuchar las mismas escenas que admiráis al verlas. Tal vez, por esta misma razón me podríais elogiar a mi y preferirme a mi rival, ya que yo no solo he hecho la declamación sino que os he proporcionado un doble placer. Observad la dificultad de mi osadía: componer tantas imágenes sin colores, formas y espacio. Desnuda está la pintura de las palabras ${ }^{47}$.

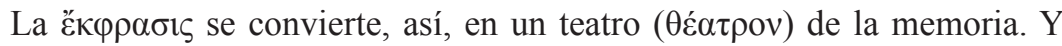
Luciano no renuncia a ofrecer algunas escenas de ese teatro cuando el segundo orador concreta su osadía en la construcción de unas imágenes verbales

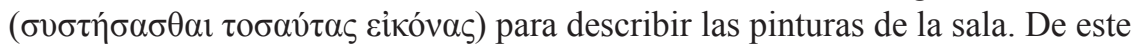
modo, los temas en ellas pintados -Perseo, Medea, Pílades y Orestes, Apolo

${ }^{46}$ Luciano arguye que la instrucción de quien contempla algo bello -y lo mismo podría aplicarse a quien escucha las palabras de un orador- influye en su percepción, al no regir "la misma ley para

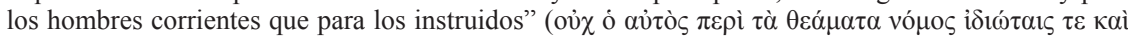

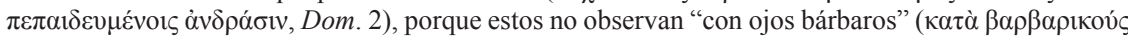
$\tau \iota v \alpha \varsigma$ ò $\varphi \alpha \lambda \mu$ ò̀, Dom. 6), sino que son capaces de articular algún razonamiento, provocado por el placer de reconocer.

${ }^{47}$ Como ya advirtiera Simónides; supra n. 2. Luciano retoma esta rivalidad entre pintura y palabra recurriendo de nuevo al adjetivo $\psi(\lambda \eta j$ cuando, para terminar su obra De mercede conductis, define con ese término la imagen sin adornos, que se propone elaborar como colofón de su exposición sobre la existencia miserable de quien vive a sueldo, y que él mismo se ve obligado a construir solo mediante sus palabras -satíricas, naturalmente-, al carecer de ilustres pintores que puedan ejecutarla

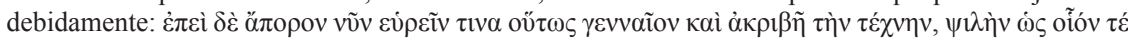

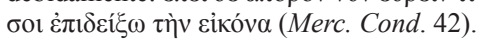


y Branco, Orión y Cedalión, Odiseo y Palamedes...-, por mor de la palabra, cobran una nueva vida ante los asistentes. No es necesario, sin embargo, explicar esas pinturas en todos sus detalles, sino que la competencia del orador, siempre amparada en la complicidad del público erudito, radica, precisamente, en su capacidad para generar en el oyente, experto y conocedor del motivo tratado por el pintor, el recuerdo de lo que ya conoce, solo con la mención de algunos pormenores relativos al mito o a la historia reproducidos en la imagen. Así, en la pintura dedicada a Medea, el orador señala unos pocos elementos esenciales -como si de palabras clave se tratara: celos, espada, niños-, susceptibles, no obstante, de evocar en los presentes la inevitable tragedia que se cierne sobre la repudiada esposa de Jasón:

\title{
Luc. Dom. 31
}

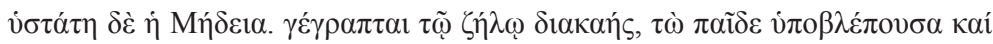

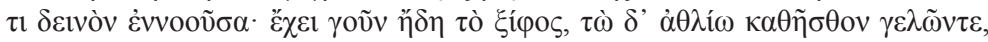

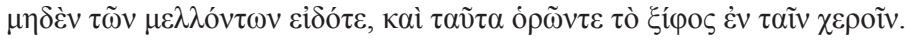

Finalmente está pintada Medea, inflamada de celos, mirando torvamente a sus dos hijos y tramando alguna atrocidad. Pues tiene ya la espada, pero ellos infortunados están sentados riendo sin saber nada de lo que les espera y eso que están viendo la espada en sus manos.

Sobre una pintura referida a Orestes y Pílades, el orador hace explícita la comunidad temática entre la poesía dramática y el motivo elegido por el pintor, cuya habilidad destaca por el tratamiento del episodio seleccionado:

\begin{abstract}
"A continuación, al lado de esta escena, está dibujada ( $\gamma \varepsilon \dot{\gamma} \gamma \rho \alpha \tau \tau \iota)$ otra acción

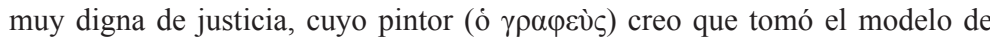
Eurípides o de Sófocles. Ellos, en efecto, han representado esta misma escena

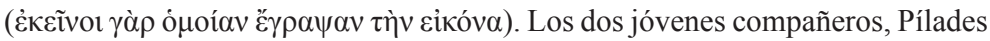
de Focea y Orestes, dado ya por muerto, entran sin ser vistos en el palacio real y dan muerte ambos a Egisto. Clitemnestra ya ha sido asesinada y yace semidesnuda sobre una cama mientras toda la servidumbre está conmocionada por esta acción: unos como si gritaran, otros miran a su alrededor donde huir. Extraordinaria fue la idea del pintor al mostrar solamente la impiedad de la empresa y pasar rozando el tema como algo ya sucedido, mientras realzaba a los jóvenes cuando se demoraban en el asesinato del adúltero" 48 .
\end{abstract}

El autor de otra pintura es calificado de $\tau \varepsilon \chi v i ́ \tau \eta \varsigma^{49}$ y alabado también por su técnica, en este caso, porque ha sido capaz de insertar una narración compleja -la liberación de Andrómeda por Perseo- en el espacio reducido

\footnotetext{
${ }^{48}$ Luc. Dom. 23.

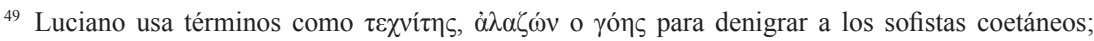
Gómez (2003: 281-284).
} 
de la 'imitación' ejecutada por el pintor, cuya habilidad artística le ha dejado transformar en imagen un relato -es decir, recorrer a la inversa el camino que el orador deshace ahora con sus palabras, convirtiendo esa imagen en discurso:

\begin{abstract}
"A la derecha, según se entra, una novela etíope está combinada con una fábula argólica. Perseo mata al monstruo marino y libera a Andrómeda, poco después se casará con ella y la llevará consigo. Este es un pasaje incidental de su vuelo al país de las Gorgonas. En poco espacio el artista ha representado mucho contenido ( $\dot{\varepsilon} v \beta \rho \alpha \chi \varepsilon \tilde{\imath} \delta \dot{\varepsilon} \pi 0 \lambda \lambda \dot{\alpha}$ ó $\tau \varepsilon \chi v i ́ \tau \eta \varsigma ~ \varepsilon \dot{\varepsilon} \mu \mu \eta \dot{\sigma} \sigma \alpha \tau$ ): el pudor de la joven, su miedo -contempla la batalla desde arriba sobre un peñasco-, la osadía del joven impulsada por el amor y la mirada invencible del monstruo. Avanza erizado de espinas y aterrorizando con sus fauces abiertas, pero Perseo con la mano izquierda le muestra la Gorgona y con la derecha le hiere con la espada. La parte del monstruo marino que mira a la Medusa, está ya petrificada, y la parte que sigue respirando es alcanzada por la hoz" ${ }^{50}$.
\end{abstract}

Las palabras del orador pueden, asimismo, transmitir la sensualidad propia de una pintura de tema amoroso, gracias, precisamente, a la brevedad de una descripción que apenas permite saber quiénes son los protagonistas de la escena:

"Luego hay un dios hermoso y un joven en la flor de la juventud, un juego amoroso. Branco, sentado sobre un peñasco, sostiene una liebre y juega con su perro que parece que va a lanzarse contra ella de un salto. Apolo, de pie a su lado, sonríe y disfruta con las dos imágenes: el juego del niño y las tentativas del perro" 51 .

\title{
Diálogo pictórico
}

Luciano realiza notables descripciones para explicar su propia condición de literato y sofista: no quiere ser admirado solo por la novedad de su declamación, como le ocurrió a Zeuxis cuando pintó una centauro, dado que él, precisamente, elogia la precisión artística del pintor y no solo la originalidad del tema tratado (Zeux. 3) $)^{52}$; se considera, a pesar de sus años, apto para la actividad oratoria, como el Heracles de cuya lengua penden cadenas que, atadas a los oídos de los hombres, los arrastran (Herc. 3-7); o bien, al presentar en Macedonia y ante

\footnotetext{
${ }^{50}$ Luc. Dom. 22. El combate de Perseo con Gorgona está pintado en otro cuadro, en cuya escueta descripción Luciano sintetiza el relato mítico; cf. Dom. 25.

${ }^{51}$ Luc. Dom. 24. Luciano cita a Branco como ejemplo de fidelidad amorosa en DDeor. 6.2. El motivo aparece en el epistolario amoroso de Filóstrato $(E p .5,8,57) \mathrm{y}$, tal vez, formara parte de los exempla mitológicos de uso escolar.

${ }^{52}$ Dubel (2014: 15) señala que Luciano, al describir obras de arte, muestra su destreza retórica, pero "la facture des œuvres d'art est bien ce qui retient l'intérêt de Lucien, alors que les autres auteurs d'ecphrasis se contentent souvent de faire l'éloge d'un sujet, oubliant presque l'artiste".
} 
un público entendido su obra, espera obtener un reconocimiento equiparable al logrado por Etión y Herodoto en Olimpia y ser valorado de acuerdo con sus méritos (Herod. 7-8).

No obstante, el ingenio del samosatense permite verificar esa íntima y necesaria conexión entre palabra y visión que Luciano expone e ilustra en $D e$ domo a partir de pinturas anónimas, también en otros textos, cuyo estudio no suele abordarse desde esta óptica. La particularidad de esos pasajes, quizás menores, pero igualmente significativos para descubrir la capacidad creativa del samosatense al amparo de la descripción -considerando que este recurso retórico no tiene solo el significado restrictivo de reseña de una obra de $\operatorname{arte}^{53}$-, es que se encuentran en obras dialógicas, de las llamadas dialogi minores, piezas breves en extensión, y de asunto mítico, cuya fianlidad es "the presentation of something familiar in a strikingly distinctive manner" ${ }^{54}$. Su brevedad, también su carácter estático desde el punto de vista del desarrollo de una acción dramática, sugiere un espacio idóneo para contar de nuevo historias bien conocidas por el público ilustrado que, sea oyente o lector, Luciano reclama siempre como destinatario de sus creaciones ${ }^{55}$.

Los Diálogos marinos destilan, en su conjunto, una imagen tranquila y placentera adecuada para acoger la narración descriptiva de episodios míticos ${ }^{56}$. Los escolios orientan sobre algunas diferencias entre los grupos de dialogi minores y, precisamente, fijan como propio de los Diálogos marinos

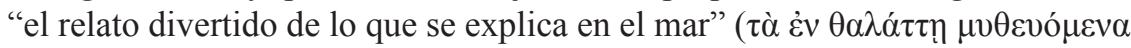
$\delta 1 \alpha \pi \alpha i ́ \zeta \varepsilon 1)^{57}$. De ellos, tal vez el más representativo del poder evocador del discurso y del efecto que toda descripción debe causar sobre el destinatario ${ }^{58}$, sea el diálogo entre los vientos Céfiro y Noto (DMar. 15).

El tema de esta charla es el mito de Europa, cuyo rapto Luciano recrea moldeando, a través del diálogo, una descripción, dado que el relato de Céfiro parece propio de quien reproduce una imagen con palabras, con el fin de que el receptor de estas pueda también ver la 'pintura' de esa escena ${ }^{59}$. A ello contribuye la iteración del verbo ópó $\omega$ y $\varphi \alpha$ ívo $\mu \alpha 1$, o la presencia de los

\footnotetext{
53 Webb (2009: 11).

${ }^{54}$ Bartley (2005: 359). Bompaire (1958: 578) se refiere a ellos en términos de "jeu littéraire et satisfaction esthétique".

55 Luc. Zeux. 1-2. Pretzler (2009: 157-171), Gómez (2012: 548-552).

${ }^{56}$ Compartidos, en ocasiones, con algunos Diálogos de dioses donde se anuncian hechos que han de suceder, y en el mar son explicados en sus pormenores por atentos espectadores, no involucrados de forma directa en esas historias. Gómez (2014a: 320-324).

57 Schol. in Luc. p. 264 Rabe. En cambio, en los Diálogos de dioses el samosatense "critica cuanto concierne a los llamados dioses del cielo en su morada" (p. 278).

58 Pigeaud (2014: 177-210) examina los efectos emocionales que, más allá de la retórica, la descripción genera en el individuo.

59 Junto al epilio Europa de Mosco y a los versos de Ovidio (met. 2.833-875), la écfrasis más extensa de este asunto mítico es la de Aquiles Tacio en Leucipa y Clitofonte (Ach. Tat. I 1.3-12).
} 
substantivos $\theta \varepsilon \dot{\varepsilon} \alpha, \theta \varepsilon \dot{\varepsilon} \alpha \mu \alpha, \theta \varepsilon \alpha \tau \alpha$ í en este diálogo ${ }^{60}$, cuya plasticidad es patente ya desde su inicio mismo. Céfiro abre la pieza asegurando haber visto una fastuosa

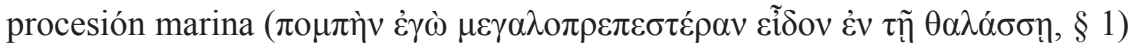

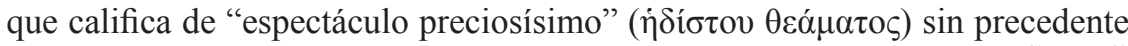

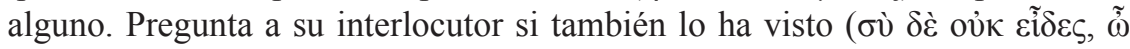
Nó $\varepsilon$;), y Noto responde que sus ocupaciones se lo han impedido; por lo tanto, Céfiro, deseoso de captar la atención de su eólico compañero, le advierte: "ya

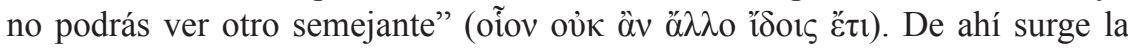
necesidad de una narración: Noto sabe quién es Europa, pero ignora a qué visión se refiere Céfiro, quien, en consecuencia, anuncia entonces que va a iniciar una exposición y cuál es su contenido: "de ella voy a hablarte” (Пepì

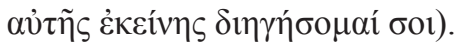

En primer lugar, Céfiro refiere con detalle la escena fenicia: en la playa, Europa juguetea con sus compañeras y Zeus comparte sus juegos, metamorfoseado en toro. Con una meticulosa descripción el suave viento justifica que la apariencia del animal resultara atractiva a las muchachas

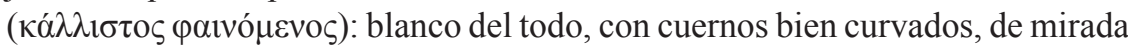
plácida y dulces mugidos. A continuación, cuenta cómo la princesa fenicia, confiada, incauta, monta sobre el animal que echa a correr hacia el mar; y cómo entonces la joven "aterrada ante lo sucedido, se aferraba al cuerno con la mano izquierda para no escurrirse, en tanto que con la otra mano sujetaba el pelo agitado por el viento" ( $\$ 2)$.

Las palabras de Céfiro logran su objetivo: presentar ante su oyente, haciéndolo visible, lo que este no vio cuando acaecía, pero que ahora sí percibe gracias al relato, e incluso es capaz de definir con los mismos términos

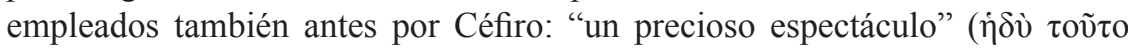
$\theta \varepsilon \dot{\varepsilon} \alpha \mu \alpha, \S 3)$.

Céfiro retoma la palabra y prosigue con la narración de lo ocurrido en un nuevo escenario: el mar. Pero antes precisa que la minuciosidad de su descripción - quizás también para justificar su verosimilitud-es posible porque los vientos, en aquella ocasión, permanecieron en calma y así pudieron observar

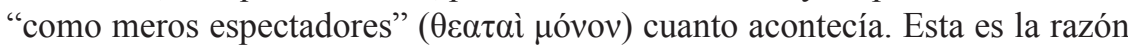
por la que Céfiro puede entonces reproducir la bella estampa de un suceso anterior en un bellísimo cuadro hecho de palabras: amorcillos volando a ras de agua y con antorchas encendidas entonando el himeneo, Nereidas cabalgando a lomos de delfines, Tritones, Afrodita esparciendo flores sobre la doncella, y "Poseidón, montado en su carro con Anfítrite a su lado, iba al frente del cortejo gozoso, abriendo camino a su hermano que nadaba".

Tras describir la comitiva marina, Céfiro interrumpe brevemente su exposición para indicar que hubo todavía un tercer escenario (“...todo esto tuvo

${ }^{60}$ Gómez (2014b: 75-86).

Araucaria. Revista Iberoamericana de Filosofía, Política, Humanidades y Relaciones Internacionales, año $21, \mathrm{n}^{\circ} 41$ Primer semestre de 2019. Pp. 233-256. ISSN 1575-6823 e-ISSN 2340-2199 doi: 10.12795/araucaria.2019.i41.11 
lugar desde Fenicia hasta Creta", § 4), donde el toro ya no se vio más (oủ

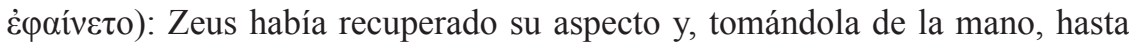
la cueva de Dicte conduce a Europa, "ruborizada y con la mirada baja, pues ya sabía para qué la llevaba allí”.

El atónito oyente, Noto, cierra el diálogo reconociéndose espectador de las palabras de su compañero, puesto que ahora ya, con pleno conocimiento, y sin duda alguna, también él puede considerar un "espectáculo" ( $\tau \tilde{\eta} \varsigma \theta \dot{\varepsilon} \alpha \varsigma$ ) la escena que no pudo observar, cuya delicada y sensual belleza, transmitida en el relato, queda también certificada por contraste con los seres que él escrutó mientras soplaba en tierras alejadas: “¡Dichoso tú, Céfiro, por el espectáculo! Yo, en cambio, estaba viendo grifos, elefantes y hombres negros!’.

\section{Reflexión final}

Los pasajes de Luciano analizados en este trabajo son solo una muestra de cómo el samosatense no desestima recurrir a la creación artística, por cuanto esta, al igual que la retórica que él practica tanto en su actividad oratoria como en la creación literaria, conjuga técnica y talento. Para ello, el samosatense se sirve de obras concretas, que atribuye a insignes artistas de la tradición griega, o bien utiliza obras anónimas de su tiempo, sean unas y otras reales o no ${ }^{61}$. Al mismo tiempo, hábil creador como es, Luciano se erige él mismo en artista plástico, en pintor, cuando con su destreza verbal muestra una capacidad singular para aplicar, en cualquier contexto discursivo, sea narrativo o dialógico, los recursos expresivos aprendidos de su formación retórica.

Si el anónimo orador de De domo declara como audaz su tarea de disertar ante las bellas pinturas de la sala de declamación ${ }^{62}$, no menos decidido en exhibir talento retórico se muestra el viento Céfiro. En ambos casos, Luciano cumple sobradamente con los requisitos de una descripción - claridad y evidencia ${ }^{63}$-, bien sea ejecutada de forma directa ante un objeto, o bien sea solo alentada por un recuerdo.

Luciano reescribe el rapto de Europa, la trágica suerte de Medea o las heroicas hazañas de Perseo mediante una visualización verbal, de modo que, mediante la descripción contenida en una exposición narrativa o en un

${ }^{61}$ El estudio de las obras de arte descritas por Luciano en sus écfrasis mayores ha priorizado una posible identificación con piezas existentes, puesto que el samosatense precisa incluso cuándo o dónde las vio. Sin embargo, para algunas de ellas, Luciano es la única fuente conservada: Zeuxis, Etión y Apeles son citados como autores respectivos de La familia del centauro, de Alejandro y Roxana, y

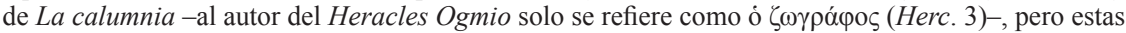
pinturas no constan en ningún catálogo legado por la Antigüedad, como el de Plinio (nat. 35-36). Detallado análisis sobre algunas de estas obras en Borg (2004: 26-48).

${ }^{62}$ Goeken (2009: 189-221).

${ }^{63}$ Dubel (1997: 249-264), Webb (2009: 87-106).

Araucaria. Revista Iberoamericana de Filosofia, Politica, Humanidades y Relaciones Internacionales, año $21, \mathrm{n}^{\circ} 41$. Primer semestre de 2019. Pp. 233-256. ISSN 1575-6823 e-ISSN 2340-2199 doi: 10.12795/araucaria.2019.i41.11 
diálogo, el público destinatario de sus obras experimenta, a través de una nueva percepción sensible, el placer de reconocer una historia ya sabida, y puede gozar de ella en términos semejantes a los que Aristóteles atribuía a la poesía.

De este modo, el orador de la magnífica sala y Céfiro actúan como intérpretes, cuya misión consiste en desvelar -de ahí la preferencia por un público instruido- algo familiar, heredado de la tradición, con el fin de que el oyente o el lector gracias a los estímulos sensoriales provocados por la sabiduría ( бoфía) del rétor, descubra un nuevo horizonte en imágenes ya presentes en su memoria, porque la palabra es el arma que controla el poder de la imagen.

Así pues, quizá no sea gratuito recordar cómo la recuperación de Luciano en época moderna tuvo mucho qué ver con las artes plásticas ${ }^{64}$. Sus palabras de arte -y siempre con arte ( $\tau \dot{\varepsilon} \chi \vee \eta)$ articuladas- sirvieron para dar vida desde el Renacimiento a nuevas imágenes, al menos a juzgar por la amplia presencia del mito de Europa en la pintura renacentista y barroca, o la pervivencia de su Heracles Ogmio junto a Retórica en los frescos de Pellegrino Tibaldi que adornan la biblioteca del Real Monasterio de El Escorial.

\footnotetext{
${ }^{64}$ Faedo (1991: 129).
} 


\section{Bibliografía:}

Andrade y Rush 2016: N. Andrade y E. Rush, "Introduction: Lucian, A Protean Pepaideumenos", Illinois Classical Studies 41.1 (2016), pp. 151-184.

Bartley 2005: A. Bartley, "Techniques of composition in Lucian's minor dialogues", Hermes 133.3 (2005), pp. 358-367.

Billault 2006: A. Billault, "Very Short Stories: Lucian's Close Encounters With Some Paintings" [en S. N. Byrne, E. P. Cueva y J. Alvares, eds., Authors, authority, and interpreters in the ancient novel: essays in honor of Gareth L. Schmeling, Eelde, 2006], pp. 47-59.

Billault 2017: A. Billault, "Le mélange des genres dans Â celui qui a dit: "Tu es un Prométhée dans tes discours "”, [en É. Marquise y A. Billault, eds., Mixis. Le mélange des genres chez Lucien de Samosate, Paris, 2017], pp. 37-48.

Bompaire 1958: J. Bompaire, Lucien écrivain. Imitation et création (Paris, 1958).

Borg 2004: B. E. Borg, "Bilder zum Hören - Bilder zum Sehen: Lukians Ekphraseis und die Rekonstruktion antiker Kunstwerke", Millennium: Jahrbuch zu Kultur und Geschichte des ersten Jahrtausends n. Chr., vol. 1 (Berlin/New York, 2004), pp. 25-57.

Brandâo 2001: J. L. Brandâo, A poética do Hipocentauro. Literatura, sociedade e discurso ficcional em Luciano de Samósata (Belo Horizonte, 2001).

Camerotto 1998: A. Camerotto, Le metamorfosi della parola. Studi sulla parodia in Luciano di Samosata (Pisa/Roma, 1998).

Cassin 1997: B. Cassin, "Procédures sophistiques pour construire l'évidence" [en C. Lévy y L. Pernot, eds., Dire l'évidence (Philosophie et rhétorique antiques), Paris, 1997], pp. 15-29.

Cribiore 2001: R. Cribiore, Gymnastics of the Mind: Greek Education in Hellenistic and Roman Egypt (Princeton, 2001).

Dobrov 2002: G. W. Dobrov, "The sophist on his craft: art, text, and selfconstruction in Lucian", Helios 29.2 (2002), pp. 173-192.

Dubel 1997: S. Dubel, "Ekphrasis et enargeia: la description antique comme parcours" [en C. Lévy y L. Pernot, eds., Dire l'évidence (Philosophie et rhétorique antiques), Paris, 1997], pp. 249-264.

Dubel 2014: S. Dubel, Portrait du sophiste en amateur d'art (Paris, 2014).

Elsner 2013: J. Elsner, "Paideia: Ancient Concept and Modern Reception", International Journal of the Classical Tradition 20.4 (2013), pp. 136-152. Faedo 1994: L. Faedo, "Le immagini dal testo" [en S. Maffei, Luciano di Samosata. Descrizioni di opere d'arte, Torino, 1994], pp. 129-142. 
Favreau Linder 2009: A.-M. Favreau Linder, "Le sophiste et son public dans les déclamations de Lucien" [en G. Abbamonte, L. Miletti y L. Spina, eds., Discorsi alla prova, Napoli, 2009], pp. 421-448.

Gassino 2010: I. Gassino, "Par-delà toutes les frontières: le pseudos dans les Histoires vraies de Lucien" [en F. Mestre y P. Gómez, eds., Lucian of Samosata, Greek writer and Roman citizen, Barcelona, 2010], pp. 87-98.

Gibson 2012: C. A. Gibson, "How (not) to learn rhetoric: Lucian's Rhetorum praeceptor as rebuttal of a school exercise", Greek, Roman and Byzantine Studies 52.1 (2012), pp. 89-110.

Goeken 2009: J. Goeken, 'Éloge et description: l'esprit du banquet dans La salle (Peri tou oikou) de Lucien" [en G. Abbamonte, L. Miletti y L. Spina, eds., Discorsi alla prova, Napoli, 2009], pp. 189-221.

Gómez 1994: P. Gómez, "De Musa a Paideia: a propósito de la Vida de Luciano" [en Actas del VIII Congreso Español de Estudios Clásicos, vol. II, Madrid, 1994], pp. 205-211.

Gómez 2003: P. Gómez, "Sofistas, según Luciano” [en J. Ma Nieto Ibáñez, ed., Lógos hellenikós. Homenaje al Profesor Gaspar Morocho Gayo, vol. I, León, 2003], pp. 277-284.

Gómez 2005: P. Gómez, "El Maestro de oradores de Luciano: ¿retrato de un sofista?" [en A. Alvar Ezquerra et al., eds., Actas del XI Congreso Español de Estudios Clásicos, vol. I, Madrid, 2005], pp. 329-340.

Gómez 2007: P. Gómez, "Luciano y la escuela" [en J. A. Fernández Delgado, F. Pordomingo Pardo y A. Stramaglia, eds., Escuela y literatura en Grecia antigua, Cassino, 2007], pp. 485-496.

Gómez 2012: P. Gómez, "De Samosata a Leiden: Luciano y Rembrandt en el espejo de Zeuxis", Lexis 30 (2012), pp. 537-564.

Gómez 2014a: P. Gómez, "Ecos del Olimpo en los Diálogos marinos de Luciano" [en A. Pérez Jiménez, ed., Realidad, Fantasía, Interpretación, Funciones y Pervivencia del Mito Griego, Zaragoza, 2014] pp. 313-328.

Gómez 2014b: P. Gómez, "Contemplar la belleza, sentenciar por las palabras: juegos de seducción en el Juicio a las diosas de Luciano”, Ordia Prima 13 (2014), pp. 65-99.

Humble y Sidwell 2006: N. M. Humble y K. Sidwell, "Dreams of glory: Lucian as autobiographer" [en B. C. McGing, J. M. Mossman y E. L. Bowie, eds., The limits of ancient biography, Swansea, 2006], pp. 213-225.

Jouanna 2001: J. Jouanna, “ГРАФEIN, 'écrire' et 'peintre': Contributions à l'histoire de l'imaginaire de le mémoire en Grèce ancienne" [en $L a$ littérature et les arts figurés de l'Antiquité à nos jours, Paris, 2001], pp. $55-70$. 
Kim 2017: L. Kim, “Atticism and Asianism" [en D. S. Richter y W. A. Johnson, eds., The Oxford Handbook of the Second Sophistic, Oxford/New York, 2017], pp. 41-66.

Maffei 1994: S. Maffei, Luciano di Samosata. Descrizioni di opere d'arte (Torino, 1994).

Marquis et Billault 2017: É. Marquise y A. Billault, eds., Mixis. Le mélange des genres chez Lucien de Samosate (Paris, 2017).

Mestre 2017: F. Mestre, "Spectacle et paideia" [en É. Marquise y A. Billault, eds., Mixis. Le mélange des genres chez Lucien de Samosate, Paris, 2017], pp. 239-255.

Mestre y Gómez 1998: F. Mestre y P. Gómez, "Les sophistes de Philostrate" [en N. Loraux y C. Miralles, eds., Figures de l'intellectuel en Grèce ancienne, Paris, 1998], pp. 333-369.

Mestre y Gómez 2001: F. Mestre y P. Gómez, "Retórica, comedia, diálogo. La fusión de géneros en la literatura griega del s. II d.C.", Myrtia 16 (2001), pp. 111-122.

Morgan 1998: T. Morgan, Literate Education in the Hellenistic and the Roman Worlds (Cambridge, 1998).

Nesselrath 1990: H.-G. Nesselrath, “Lucian's Introductions” [en D. A. Russell, ed., Antonine Literature, Oxford,1990], pp. 111-140.

Newby 2002: Z. Newby, “Testing the Boundaries of Ekphrasis: Lucian On The Hall”, Ramus 31 (2002), pp. 126-135.

Ní Mheallaigh 2014: K. Ní Mheallaigh, Reading Fiction With Lucian. Fakes, Freaks and Hyperreality (Cambridge, 2014).

Pernot 1993: L. Pernot, La rhétorique de l'éloge dans le monde gréco-romain (Paris, 1993).

Pernot 2011: L. Pernot, "Phidias à la barre" [en L. Pernot, ed., La rhétorique des arts, Paris, 2011], pp. 11-43.

Pigeaud 2014: J. Pigeaud, "Lucien et l'ekphrasis" [en S. Dubel, Portrait du sophiste en amateur d'art, Paris, 2014], pp. 177-210.

Pretzler 2009: M. Pretzler, "Form over Substance? Deconstructing Ecphrasis in Lucian's 'Zeuxis' and 'Eikones'" [en A. Bartley, ed., A Lucian for our Times, Cambridge, 2009], pp. 157-171.

Quiroga 2007: A. J. Quiroga, "From sophistopolis to episcopolis. The Case for a Third Sophistic", Journal for Late Antique Religion and Culture 1 (2001), pp. 31-42.

Richter y Johnson 2017: D. S. Richter y W. A. Johnson, eds., The Oxford Handbook of the Second Sophistic (Oxford/New York, 2017). 
Squire 2015: M. Squire, "Ecphrasis: Virtual Interactions in Ancient Greek and Latin Literature", Oxford Handbooks Online (DOI: 10.1093/oxfordhb/ 9780199935390.013.58) [consulta: 15/11/2018].

Webb 2001: R. Webb, "The Progymnasmata as Practice" [en Y. L. Too, Education in Greek and Roman Antiquity, Leiden, 2001], pp. 289-316.

Webb 2009: R. Webb, Ekphrasis, Imagination and Persuasion in Ancient Rhetorical Theory and Practice (Farnham, UK/Burlington, VT, 2009).

Webb 2017: R. Webb, "Schools and Paideia" [en D. S. Richter y W. A. Johnson, eds., The Oxford Handbook of the Second Sophistic, Oxford/ New York, 2017], pp. 139-153.

Whitmarsh 2001: T. Whitmarsh, Greek Literature and the Roman Empire. The Politics of Imitation (Oxford, 2001).

Whitmarsh 2005: T. Whitmarsh, The Second Sophistic (Oxford, 2005). 